Personalidade Acadêmica Homenageada:

Raymundo Juliano Feitosa (Universidade Federal do Rio Grande do Norte - UFRN)

\title{
“PRIVILÉGIO NEGRO”: UM PANORAMA SOBRE O INGRESSO DE PESSOAS NEGRAS NOS CURSOS SUPERIORES DE DIREITO PELO SISTEMA DE COTAS EM MINAS GERAIS
}

\section{WESLEY BARTOLOMEU FERNANDES DE SOUZA}

Graduando em Direito, modalidade integral, pela Escola Superior Dom Helder Câmara - Belo Horizonte - MG. E-mail: wesleybartolomeu@gmail.com

\section{CAIO AUGUSTO SOUZA LARA}

Mestre e Doutor em Direito pela Faculdade de Direito da Universidade Federal de Minas Gerais - UFMG. Professor da Escola Superior Dom Helder Câmara. Pesquisador Associado ao Programa RECAJ-UFMG - Acesso à Justiça e Solução de Conflitos. Secretário de Comunicação do Conselho Nacional de Pesquisa e Pósgraduação em Direito - CONPEDI. Belo Horizonte-MG. E-mail: caiolarabh@yahoo.com.br.

\section{RESUMO}

O tema-problema da pesquisa que se pretende desenvolver é o estado e efetividade do sistema de cotas nos cursos superiores de Direito em Minas Gerais, bem como a situação das pessoas negras presentes nesses cursos. O interesse pela presente pesquisa surgiu a partir da constatação de que os negros ainda estão em um número menor nas universidades, em especial nos cursos mais prestigiados, como o Direito, Engenharia e Medicina. O negro foi em grande parte, criminalizado, e tal constatação encontra-se até mesmo presente em ações tomadas pelo governo em anos anteriores. O Código Penal de 1890 trazia consigo uma espécie de branqueamento da raça brasileira, e proibia as manifestações da cultura negra, como a capoeira, a feitiçaria, o curandeirismo etc., isto é, foram consideradas práticas 


\section{Personalidade Acadêmica Homenageada:}

Raymundo Juliano Feitosa (Universidade Federal do Rio Grande do Norte - UFRN)

criminais. Segundo Flauzina (2008), "o Código cuidou de regulamentar e qualificar como delito o ócio, mesmo o forçado, como é caso de negro(a)s desempregado(a)s e sem qualquer possibilidade de uma vida digna." A Declaração Universal dos Direitos Humanos afirma em seu artigo $26^{\circ}$ que todo ser humano tem direito à educação. Logo, deve-se prezar por respeitá-lo e buscar formas de garanti-lo a todos os indivíduos. Ademais, a Constituição da República Federativa do Brasil, assegura no artigo 205 que a educação, direito de todos e dever do Estado e da família, será promovida e incentivada com a colaboração da sociedade, visando ao pleno desenvolvimento da pessoa, seu preparo para o exercício da cidadania e sua qualificação para o trabalho. Daí salienta-se que o Estado tem o dever de efetivar o direito supracitado. Tendo em vista o contexto histórico que o negro enfrentou, ressalta-se que o Estado deve garantir formas de inclusão dessas pessoas nos diferentes âmbitos sociais. Alguns indivíduos manifestam-se contrários à implementação do sistema de cotas, gerando grandes polêmicas, como por exemplo o julgamento do Recurso Extraordinário (RE 597285) no STF, em 2012. Os ministros da suprema corte do país, em sua maioria negaram o recurso e reconheceram a constitucionalidade do sistema. O problema objeto da investigação científica proposta é: as ações afirmativas, por meio do sistema de cotas raciais têm promovido a inclusão social dos afrodescendentes, do negro brasileiro? A partir das reflexões preliminares sobre o tema, é possível afirmar inicialmente que as ações afirmativas por meio do sistema de cotas raciais, em tese, têm buscado a inclusão social dos negros e afrodescendentes, entretanto, lacunas são encontradas e elas costumam não ter total eficiência como deveriam e tornam em algumas vezes, ineficaz a inclusão destes. O objetivo geral do trabalho é analisar como tem sido o ingresso e permanência de pessoas negras nos cursos superiores de Direito em Minas Gerais utilizando o sistema de cotas. A pesquisa que se propõe pertence à vertente metodológica jurídico-sociológica. No tocante ao tipo de investigação, foi escolhido, na classificação de Witker (1985) e Gustin (2010), o tipo jurídico-projetivo. O raciocínio desenvolvido na pesquisa será predominantemente dedutivo. De acordo com a técnica de análise de conteúdo, afirma-se que trata-se de uma pesquisa teórica, o que será possível a partir da análise de conteúdo dos textos doutrinários, normas e demais dados colhidos na pesquisa. Como conclusão parcial 
Personalidade Acadêmica Homenageada:

Raymundo Juliano Feitosa (Universidade Federal do Rio Grande do Norte - UFRN)

do trabalho, tem-se que existem fraudes no sistema de cotas raciais, mas elas têm sido eliminadas aos poucos por meio de comissões especiais, algumas formadas inclusive por pessoas negras, e outras medidas tomadas pelas universidades públicas situadas no Estado de Minas Gerais. Embora tais medidas estejam sendo tomadas, as pessoas negras ainda são minoria nos cursos superiores de Direito.

PALAVRAS-CHAVE: Cotas Raciais; Direito; Negro; Universidade; Educação.

\section{REFERÊNCIAS}

ALMEIDA, Carlos Alberto Lima de. O curso de Direito e a questão racial. Revista Jurídica - UNICURITIBA, Curitiba, v. 1, n. 42, p. 179 - 213, 2016. Disponível em: http://revista.unicuritiba.edu.br/index.php/RevJur/article/view/1490/1019. Acesso em: 20 maio 2019.

BARRETO, Fernando Antonio Reale. A efetividade da igualdade e o sistema de cotas em concurso público. In: Direitos Sociais e Políticas Públicas I. Coordenadores: Juvêncio Borges Silva; Paulo Roberto Barbosa Ramos; Rogerio Luiz Nery da Silva Florianópolis: CONPEDI, $2017 . \quad$ Disponível em: http://conpedi.danilolr.info/publicacoes/roj0xn13/2070z86p/z2DK06pUd9WrwEZU.pdf . Acesso em: 10 maio 2019.

BRASIL. (1988). Constituição da República Federativa do Brasil. Disponível em: http://www.planalto.gov.br/ccivil_03/constituicao/constituicao.htm. Acesso em: 12 maio 2019.

Decreto № 9.427, de 28 de junho de 2018. Reserva aos negros trinta por cento das vagas oferecidas nas seleções para estágio no âmbito da administração pública federal direta, autárquica e fundacional. Disponível em: http://www.in.gov.br/materia//asset_publisher/Kujrw0TZC2Mb/content/id/27934784/do1-2018-06-29-decreto-n-9427-de-28-de-junho-de-2018-27934697. Acesso em 26 abr. 2019.

FERNANDES, Florestan. A integração do negro na sociedade de classes. São Paulo: Companhia Editora Nacional, 1965. FREIRE, Paulo. Educação como prática da liberdade. Rio de janeiro: Paz e Terra, 2003.

FLAUZINA, Ana Luiza Pinheiro (2008). Corpo negro caído no chão. O Sistema Penal e o Projeto Genocida do Estado Brasileiro. Rio de Janeiro: Contraponto.

FREIRE, Paulo. Educação como prática da liberdade. Rio de janeiro: Paz e Terra, 
Personalidade Acadêmica Homenageada:

Raymundo Juliano Feitosa (Universidade Federal do Rio Grande do Norte - UFRN)

2003.

FRY, Peter; MAGGIE, Yvonne (2004). Cotas raciais: construindo um país dividido? Econômica, vol. 6, n. 1, Rio de Janeiro. NASCIMENTO, Abdias do. O genocídio do negro brasileiro: processo de um racismo mascarado. Rio de Janeiro: Editora Paz e Terra S/A, 1978.

GUSTIN, Miracy Barbosa de Sousa; DIAS, Maria Tereza Fonseca. (Re)pensando a pesquisa jurídica: teoria e prática. 3ª . ed. Belo Horizonte: Del Rey, 2010.

NASCIMENTO, Abdias do. O genocídio do negro brasileiro: processo de um racismo mascarado. Rio de Janeiro: Editora Paz e Terra S/A, 1978.

NASCIMENTO, Abdias; NASCIMENTO, Elisa Larkin. Apresentação. In: Quilombo: vida, problemas e aspirações do negro. Edição fac-similar do jornal dirigido por Abdias do Nascimento. São Paulo: Fundação de Apoio à Universidade de São Paulo, Editora 34, 2003.

QUERO, Caio. Após ação afirmativa, negros enfrentam preconceito na universidade e no trabalho. Portal BBC News Brasil. 13 maio 2013. Disponível em: https://www.bbc.com/portuguese/noticias/2013/05/130507_negros_mdb_cq. Acesso em: 08 abr. 2019.

WITKER, Jorge. Como elaborar uma tesis en derecho: pautas metodológicas y técnicas para el estudiante o investigador del derecho. Madrid: Civitas, 1985. 